\title{
PEMANFAATAN TEKNOLOGI SEBAGAI PEMBELAJARAN E-LEARNING GOOGLE CLASSROOM PADA MATA PELAJARAN IPS
}

\author{
Mu'ayyadah ${ }^{1}$, Noor Fatmawati ${ }^{2}$ \\ ${ }^{1}$ Institut Agama Islam Negeri Kudus, \\ kahfeeya@gmail.com \\ ${ }^{2}$ Institut Agama Islam Negeri Kudus, \\ Noor.fatmawati@gmail.com
}

\begin{abstract}
ABSTRAK
Pandemi COVID-19 memberikan pengaruh fundamental terhadap sendi umat manusia. Berawal dari kesehatan pandemi ini menyerang kepada ranah pendidikan. Pemberlakuan regulasi dengan menjaga jarak kurang lebih satu meter menimbulkan konsekuensi terhadap proses pendidikan di Indonesia. Konsekuesni itu mengharuskan elemen pendidikan mengadakan proses pembelajaran jarak jauh. Istilah ini ialah mengadakan pembelajaran sebagai pengganti metode tatap muka agar tetap terselenggarakannya pendidikan yang tidak bisa digangggu gugat oleh keadaan apapun. Situasi ini memicu kondisi penggunaan teknologi sebagai alternatif pembelajaran jarak jauh. Penerapan pembelajaran jarakjauh dapat menggunakan teknologi, sebagai pembelajaran E-Learning. Guru semakin dituntur mengoperasikan teknologi khususnya IPS yang mana selama ini cenderung apatis dan tradisionalis dalam metodenya. E-Learning memunculkan koneksi internet dan teknologi informasi yang mendukung proses pembelajaran daring yaitu google classroom. Dalam tulisan ini, peneliti menitikberatkan pada penggunaan teknologi untuk pembelajaran online dengan mengggunakan aplikasi google classroom di materi IPS. Ilmu pengetahuan sosial berdampak pada situasi sosialnya lalu penggunaan teknologi sangat bermanfaat dalam pelaksanaan pembelajaran daring.
\end{abstract}

Kata Kunci: Teknologi, IPS, E-Learning Google Classroom.

\section{ABSTRACT}

The COVID-19 pandemic has a fundamental influence on the joints of humanity. Starting from the health of this pandemic, it attacks the realm of education. The 
enforcement of regulations by maintaining a distance of approximately one meter has consequences for the education process in Indonesia. This consequence requires that the educational elements carry out a distance learning process. This term is to provide learning as a substitute for face-to-face methods so that education can be held that cannot be disturbed by any circumstances. This situation triggers the use of technology as an alternative to distance learning. The application of distance learning can use technology, as E-Learning. Teachers are increasingly being frightened by operating technology, especially social studies, which have tended to be apathetic and traditionalist in their methods. E-Learning creates an internet connection and information technology that supports the online learning process, namely google classroom. In this paper, the researcher focuses on the use of technology for online learning by using the google classroom application in social studies material. Social science has an impact on their social situation and the use of technology is very useful in implementing online learning.

Keywords: Technology, Social Science Education E-Learning, Google Classroom.

\section{PENDAHULUAN}

Dunia dikejutkan dengan berita ditemukannya virus Corona yang penyebabnya belum diketahui pada akhir desember $2019 .{ }^{1}$ Virus ini dinamakan corona karena bentuknya seperti mahkota yang menyerang organ pernapasan manusia. Sejak pertama kali di Wuhan, Hubei, China kian hari menyebar ke negara-negara sekitarnya seperti seperti hongkong, Macau. dan Taiwan, sampai pada satu bulan lamanya Wuhan memberitahu organisasi kesehatan dunia (WHO) bahwa akan terjadinya wabah yang kali ini disebut dengan COVID 19.

Virus ini bersarang di tubuh manusia dan dapat menularkannya lewat kontak langsung dengan penderita, waktu demi waktu berjalan, virus ini telah menyebar ke penjuru dunia tak terkecuali Indonesia. Kasus pertama kali bahwa adanya COVID 19 sampai di Indonesia adalah seorang ibu dan anaknya di daerah Jawa Barat positif COVID 19, dan penyebarannya sampai merebak ke penjuru Indonesia. Hal ini dikarenakan jarak kontak langsung tidak berjarak dan kelalaian mengenakan masker dan mencuci tangan. Akibatnya banyak lini kehidupan masyarakat menjadi terganggu.

COVID 19 berkontribusi pada kesulitan di berbagai sektor kehidupan masyarakat diantaranya ke sektor Pendidikan. Pendidikan merupakan implementasi amanat undang-undang dasar 1945 yang tertera di tujuan nasional yang keempat yakni mencerdaskan kehidupan bangsa. Dalam upayanya usaha terus digalakkan salah satunya di situasi pandemi ini yang memunculkan persoalan. Realitas permasalahan yang terjadi adalah pemberlakuan pembelajaran

1 Maya Mahitsa Agung Mahardini. (2020). Analisis Situasi Penggunaan Google Classroom Pada Pembelajaran Daring Fisika. Jurnal Pendidikan Fisika, 8(2), hal 216. 
sekolah yang semula dengan kegiatan ruang kelas tatap muka menjadi pembelajaran jarak jauh di tempat tinggal masing-masing. Adanya kondisi ini sesuai dengan keputusan pemerintah, khususnya Kementerian Pendidikan dan Kebudayaan tentang proses belajar dilakukan di rumah saja dengan metode daring, Pemberlakuan ini dilegalisasikan dengan Kementerian Pendidikan dan Kebudayaan mengeluarkan pemberitahuan nomor 36962 / MPK.A / HK / 2020 tentang belajar online selama darurat bencana COVID 19 pada 27 Maret 2020.

Pilihan terhadap alternatif proses pembelajaran di masa pandemi dengan menerapkan metode daring memang memiliki tujuan dalam menekan laju penyebaran COVID 19. Bahkan kebijakan yang diambil pemerintah secara dini tentang pembatalan UN pada tahun depan dipercepat di tahun ini, akan tetapi pemerintah menggantinya dengan US melalui metode daring pula. Kategori indikator kelulusan berbentuk penilaian jarak jauh yakni mencakup portofolio, nilai rapor, dan penugasan. Dengan pemberlakuan metode daring di pembelajaran sekolah justru menimbulkan problem baru di tengah daruratnya pendidikan. $^{2}$

Permasalahan semakin mengakar, pemberlakuan metode daring berkesempatan mengganggu psikis peserta didik dan pendidik. Sebabnya pemerataan pendidikan yang masih belum maksimal, daya operasi teknologi inforasi dan komunikasi berbeda-beda, serta kemampuan beragam pula. Hal ini telah disinggung Komisi Perlindungan Anak Indonesia (KPAI) menyatakan bahwa karena banyak siswa yang salah paham tentang pembelajaran online dan menyelesaikan banyak tugas, efek penggunaan pembelajaran online menjadi buruk. 18 Maret 2020. ${ }^{3}$

Atas beberapa masalah yang berkembang cukup menyadarkan diri untuk menerimanya dan mengharapkan pandemi ini segera usai sehingga kenormalan sedia kala bisa terjadi. Menjalani roda kehidupan di masa ini cukup berat, akan tetapi untuk mensiasati ada terobosan baru bagi pelaku pendidikan untuk tetap melaksanakan kegiatan belajar mengajar dengan daring. Istilah daring ini tidak asing karena sebelum masa pandemi sudah ada masa yang disebut dengan era globalisasi.

Arti globalisasi yang memudahkan penggunaan teknologi canggih dari negara maju hingga berkembang seperti Indonesia yang dikenal dengan sebutan global village. Manfaat yang bisa diambil dari terbukanya ruang kebebasan akses adalah bisa mendayafungsikan kemudahan teknologi dengan baik supaya

2 Rizki Setiawan, Eti Komalasari. (2020). Membangun Efektivitas Pembelajaran Sosiologi Di Tengah Pandemi COVID-19. Edusocius, 4(1), hal.3.

3 Dede Rahmat Hidayat, Ana Rohaya, Fildzah Nadine, \& Hary Ramadhan. (2020). Kemandirian Belajar Peserta Didik Dalam Pembelajaran Daring Pada Masa Pandemi COVID -19. Perspektif Ilmu Pendidikan, 34(2), hal 149. 
dapat mengejar ketertinggalan negara lain karena masyarakat tidak mampu memanfaatkan secara optimal. ${ }^{4}$

Bentuk pemanfaatan itu bisa diterapkan di masa pandemi ini, pandemi memberi momentum pembenahan proses pembelajaran daring dengan kebanyakan menggunakan media sosial kini bisa dialihfungsikan kepada media khusus pembelajaran. Guru dituntut berkreasi dan berinovasi sesuai perkembangan zaman dan dalam keadaan serta situasi apapun. Salah satu memanfaatkan teknologi dalam proses pembelajaran daring adalah menggunakan sistem e-learning. Penggunaan kata e pada learning mengubah paradigma dalam seluruh aspek kehidupan, dengan munculnya paradigma e memicu untuk lebih baik, lebih cepat, dan efisiensi waktu. Maka dari itu pada proses pembelajaran daring sistem e-learning bisa dikatakan inovasi pembelajaran di masa pandemic khususnya dalam mata pelajaran IPS. Dalam artikel ini, pemanfaatan teknologi sebagai inovasi pembelajaran IPS dengan menggunakan metode daring melalui web atau aplikasi google kelas atau classroom. Istilah google classroom adalah perangkat lunak belajar online yang dapat dipakai di semua bidang pendidikan untuk membantu guru berbagi kepada siswa pengetahuan dalam bentuk dokumen sebagai aktivitas pembelajaran daring.

Sering kali mendengar bahwa pembelajaran IPS terkenal membosankan dibanding pembelajaran yang lain. Namun apabila guru dapat menggunakan media pembelajaran yang menarik akan memotivasi siswa untuk berpartisipasi aktif dalam proses pembelajaran. Oleh karena itu, peran guru sangat penting dalam membentuk sikap siswa terkait materi IPS di kelas. Guru aktif bersedia membantu siswa belajar, menunjukkan antusiasme di kelas dan memperhatikan kebutuhan mereka. Hal ini mampu membuat siswa tertarik dan memahami materi pembelajaran dengan baik meskipun dengan tanpa tatap muka. ${ }^{5}$

Inovasi pembelajaran merupakan gagasan dan terobosan terbaru bagi pendidik agar terciptanya proses pembelajaran yang efektif di masa pandemi seperti ini. Hal ini bertujuan mewujdukan transformasi pengetahuan yang cepat dan mudah diakses bagi setiap pendidik. ${ }^{6}$ Perhatian guru juga sebagai inovasi apalagi disaat pandemi seperti ini, dimana tatap muka dilarang maka pengguanaan media daring merupakan bentuk perhatian supaya materi IPS bisa dipelajari. Salah satu media yang digunakan dalam metode daring adalah google classroom. Alasan penggunaan google classroom dimungkinkan keefektifannya

4 Kukuh Andri Aka. (2017). Pemanfaatan Teknologi Informasi Dan Komunikasi (TIK) Sebagai Wujud Inovasi Sumber Belajar Di Sekolah Dasar. ELSE, 1(2a), hal. 29.

5 Durotun Nafisah, Abd. Gofur. 2020. Pengembangan Media Pembelajaran Scan Barcode Berbasis Android Dalam Pembelajaran IPS. EduTeach: Jurnal Edukasi dan Teknologi Pembelajaran, 1 (2) Hal. 151.

6 Maya Mahitsa Agung Mahardini. (2020). Analisis Situasi Penggunaan Google Classroom Pada Pembelajaran Daring Fisika. Jurnal Pendidikan Fisika, 8(2), hal 218. 
mengingat banyak permasalahan muncul di kalangan siswa, mulai dari banyaknya kuota yang diperlukan, jaringan sinyal susah, muat memeori handphone sedikit, dan tidak semuanya memiliki laptop sebagai alternatif medianya sehingga penggunaan google classroom dapat dapat digunakan sebagai media belajar di masa pandemi. Oleh karena itu rumusan masalah nanti dibahas adalah sebagai berikut:

1. Bagaimana pemanfaatan teknologi modern terkait pembelajaran IPS?

2. Bagaimana keterkaitan pembelajaran e-learning teknologi di pembelajaran IPS?

3. Bagaimana inovasi pembelajaran IPS menggunakan google classroom?

Sehingga tujuan tulisan ini adalah sebagai berikut:

1. Untuk mengetahui bagaimana pemanfaatan teknologi terkait pembelajaran IPS.

2. Untuk mengetahui bagaimana keterkaitan pembelajaran e-learning teknologi di pembelajaran IPS.

3. Untuk mengetahui bagaimana inovasi pembelajaran IPS menggunakan google classroom.

Sedangkan manfaat yang diberikan adalah untuk menggalakkan media google classroom sebagai alternatif pembelajaran daring.

\section{METODE PENELITIAN}

Artikel ini termasuk jenis penelitian pustaka (studi pustaka atau penelitian kepustakaan), yaitu rangkaian kegiatan yang bersinggungan dengan membaca, dan menggunakan model pengumpulan data perpustakaan untuk mencatat dan mengolah bahan tertulis. ${ }^{7}$ Alasan dimasukkan dalam jenis penelitian sastra ini karena kegiatan penelitiannya berfokus pada analisis teks yang akan diteliti. Dalam kegiatan penelitian ini hampir semua substansi perlu ditangani secara filosofis (teoritis) dan terkait dengan nilai, namun realitas tetap perlu didasarkan pada pengalaman. ${ }^{8}$ Penelitian ini dilakukan dengan mengumpulkan data / informasi dari berbagai perpustakaan di perpustakaan atau tempat lain misal buku, jurnal online, dan koran online. ${ }^{9}$ Ada empat ciri utama studi pustaka yang perlu diperhatikan:

1. Peneliti menggabungkan teks atau data digital secara tatap muka, dan menggabungkan pengetahuan langsung dari tempat kejadian atau saksi (saksi) dalam bentuk kejadian, orang atau benda lain.

7 Moh. Nazir, Metode Penelitian, Ghalia Indonesia, Jakarta, 1999, hlm. 112.

8 Noeng Muhadjir, Metodologi Penelitian Kualitatif, Rake Sarasin, Yogyakarta, 2002, hlm. 297.

9 Marzuki, Metodologi Riset, Ekonisia, Yogyakarta, 2005, hlm. 14. 
2. Peneliti tidak akan kemana-mana, artinya hanya melakukan penelitian langsung terhadap bahan sumber bacaan yang diperoleh agar data perpustakaan memiliki nilai siap pakai.

3. Peneliti mendapatkan bahan bekas dari lapangan daripada data asli tangan pertama, sehingga data perpustakaan biasanya merupakan bahan bekas.

4. Peneliti berurusan dengan informasi statis dan tetap. Artinya kemanapun ia datang dan pergi, data tersebut tidak akan pernah berubah karena sudah tersimpan data yang tidak valid dalam catatan tertulis. ${ }^{10}$

Dalam artikel ini, data pustaka beberapa jurnal terkait dihimpun dan ditelaah atau tulisan yang relevan semacam penelitian ini.

\section{HASIL DAN PEMBAHASAN}

\section{Pemanfaatan Teknologi Modern}

Perkembangan teknologi semakin canggih, masyarakat dituntut mengikutinya, tak terkecuali adalah guru sebagai tenaga pendidik. Menguasai teknologi komunikasi dan informasi menjadi tuntutan kompentensi saat ini, dalam rangka menunjang pelaksanaan pembelajaran sebagai kewajiban, setiap guru harus dapat terus belajar untuk memenuhi persyaratan kemampuan tersebut. Di zaman globalisasi seperti ini para guru dengan kesan "gagap teknologi" harus ditepis karena sudah tidak ada zamannya. Dengan harapan kehadiran teknologi adalah menjadi satu kesatuan pembelajaran, sehingga siswa lebih aktif dan mandiri. ${ }^{11}$

Istilah teknologi biasanya disertai dengan informasi dan komunikasi karena hal ini memberikan dua pengertian yang berbeda. Teknologi informasi mencakup semua hal yang berkaitan dengan pemrosesan dan manajemen informasi. Pada saat yang sama, Teknologi komunikasi adalah segala sesuatu yang berkaitan dengan penggunaan alat untuk memproses dan mengirimkan informasi dari satu perangkat ke perangkat lainnya.

Cakupan berkenaan dengan transfer pengetahuan dari pendidik ke peserta didik juga dibantu oleh teknologi komunikasi. Buktinya guru menyampaikan materi dan penugasan serta pengumpulan data diartikan sebagai bentuk komunikasi dua arah antara siswa dan guru. ${ }^{12}$

Studi mata pelajaran IPS sangat membutuhkan bantuan teknologi di kondisi pandemi, bahkan semua mata pelajaran yang diajarkan di satuan

${ }^{10}$ Mestika Zed, Metode Penelitian Kepustakaan, Yayasan Pustaka Obor Indonesia, Jakarta, 2014, hlm. 4-5.

11 Kukuh Andri Aka. (2017). Pemanfaatan Teknologi Informasi Dan Komunikasi (TIK) Sebagai Wujud Inovasi Sumber Belajar Di Sekolah Dasar. ELSE, 1(2a), hal. 30-31.

12 Kukuh Andri Aka. (2017). Pemanfaatan Teknologi Informasi Dan Komunikasi (TIK) Sebagai Wujud Inovasi Sumber Belajar Di Sekolah Dasar. ELSE, 1(2a), hal. 30-31. 
lembaga pendidikan. Pembelajaran online tidak hanya merupakan kegiatan yang dapat dilakukan secara tatap muka, tetapi juga dapat dilakukan melalui sistem pembelajaran jarak jauh, istilah tersebut biasa disebut pembelajaran online. Belajar online adalah sistem yang menggunakan peralatan jaringan komputer dan akses internet dalam mengakses belajar. Jika pembelajaran online didukung oleh komponen-komponennya, ini mungkin pilihan terbaik. Beberapa komponen tersebut adalah;

1. Infrastruktur e-learning, termasuk perangkat computer, jaringan internet dan perangkat telekonferensi.

2. Sistem dan aplikasi e-learning, termasuk sistem perangkat lunak yang digunakan,

3. Isi e-learning, termasuk buku teks dalam format multimedia atau teks. ${ }^{13}$

Media teknologi komunikasi antara pendidik dan peserta didik salah satunya dengan perangkat keras smarthphone. Smarthphone merupakan alat komunikasi yang bergerak dan dapat mengirim data berbentuk gambar, kata, dan video. Media ini sebagai sarana perangkat lunak google classroom yang mana penunjang kegiatan pembelejaran masa pandemi. Selain fungsi utama alat komunikasi kelebihan lainnya adalah kemudahan membawa karena cukup ringan dan mudah. Menjadi singgah sejumlah aplikasi yang memudahkan penyampaian informasi. Maka tak diragukan alat atau media ini bisa digunakan sebagai pemanfaatan teknologi. ${ }^{14}$

\section{Pembelajaran E-Learning}

Pembelajaran daring ini membahas tentang sistem dan aplikasi yang disebut dengan istilah e-learning. E-learning merupakan bentuk variasi kegiatan pembelajaran yang memberikan suasana berbeda dari biasanya kepada siswa sehingga terhindar dari kesan membosankan di dalam kelas dengan memanfaatkan teknologi informasi dan media online. Teknologi tersebut bervariasi dari menggunakan teknologi kabel hingga menggunakan gelombang radio (nirkabel).

Dalam teknologi terdapat sistem aplikasi umum yang terkenal dengan e-learning. Pembelajaran e-learning bermanfaat bagi pelajar dalam memberikan tranfer pengetahuan metode daring, dan memberikan suasana lain sehingga kebosanan bisa dihindarkan. Pembelajaran e-learning kegiatan pembelajaran yang merubah dari sistem konvensional ke sistem modern. Penggunaan google classroom dalam pembelajaran e-learning memuat alasan keterbatasan biaya

${ }^{13}$ Maya Mahitsa Agung Mahardini. (2020). Analisis Situasi Pengggunaan Google Classroom Pada Pembelajaran Daring Fisika. Jurnal Pendidikan Fisika, 8(2), hal 149.

14 Kukuh Andri Aka. (2017). Pemanfaatan Teknologi Informasi Dan Komunikasi (TIK) Sebagai Wujud Inovasi Sumber Belajar Di Sekolah Dasar. ELSE, 1(2a), hal. 15. 
dalam membeli kuota, atau jaringan sinyal yang tidak memadai sehingga video conference tidak bisa dilakukan, materi yang terkadang memiliki ukuran besar sehingga memori HP penuh, serta penugasan yang tidak bisa terintegrasi dengan baik. Maka menggunakan google classroom ini sebagai medianya. ${ }^{15}$

Alasan itu bisa dibenarkan karena kebutuhan di zaman sekarang terbatasi oleh keadaan, tapi dalam pembelajaran IPS lebih berkontribusi lagi. IPS Terpadu sangat relevan, karena pendekatan terintegrasi dalam IPS membutuhkan tema yang fungsinya untuk menggabungkan konsep yang satu dengan yang lain. Perkembangan topik pembelajaran penelitian sosial membutuhkan media dan sumber belajar yang luas dan informatif. Penggunaan e-learning dapat memperkaya sumber informasi topik yang dikembangkan dalam pembelajaran. Melalui penggunaan e-learning dapat diperoleh berbagai bentuk informasi, antara lain informasi tertulis atau dokumen, sumber lisan, dan hasil performance yang terlihat. Hasil tersebut dapat dilihat melalui visualisasi melalui media e-learning. 1 Penggunaan pembelajaran selanjutnya akan mengubah beberapa paradigma pembelajaran penelitian sosial, baik tertulis maupun terdokumentasi, sumber lisan, dan hasil kinerja yang terlihat, hasil tersebut dapat dilihat melalui visualisasi melalui media e-learning. Penggunaan e-learning selanjutnya akan mengubah beberapa paradigma penelitian dan pembelajaran sosial baik dalam bentuk materi, metode pembelajaran, maupun kegiatan pembelajaran. ${ }^{16}$ Pada pembahasan ini lebih ditekankan pada media pembelajaran dan keaktifan para siswa atau pelajar. ${ }^{17}$ Pada pembahasan ini lebih ditekankan pada media pembelajaran dan keaktifan para siswa atau pelajar.

Penerapan e-learning akan dilakukan agar pelajar mampu membagi waktu untuk melatih kemandirian dan tanggung jawabnya. Sebabnya adalah e-learning dianggap mampu menarik dan membuat siswa aktif di kegiatan pembelajaran. Siswa merancang dan menemukan materi melalui upaya dan inisiatif mereka sendiri. Selama ini berdasarkan fakta empiris, di tingkat sekolah, dalam IPS, proses pembelajaran. Kenyataanya guru masih belum maksimal dalam mendayafungsikan pembelajaran IPS dengan kesan pendekatan materi yang terpusat paada guru, guru hanya memainkan media tekstual buku dan

15 Dede Rahmat Hidayat, Ana Rohaya, Fildzah Nadine, \& Hary Ramadhan. (2020). Kemandirian Belajar Peserta Didik Dalam Pembelajaran Daring Pada Masa Pandemi COVID -19. Perspektif Ilmu Pendidikan, 34(2), hal 150.

16 Nur Lailatus Zahroh. 2015. Nur Lailatus Zahroh. 2015. E-learning Sebagai Inovasi Dalam Pemeblajaran IPS Tantangan Dan Peluang. Seminar Nasional Teknologi Pendidikan UM. Hal. 502.

17 Nur Lailatus Zahroh. 2015. Nur Lailatus Zahroh. 2015. E-learning Sebagai Inovasi Dalam Pembelajaran IPS Tantangan Dan Peluang. Seminar Nasional Teknologi Pendidikan UM. Hal. 502. 
metode ceramah. Oleh karena itu, jika banyak siswa yang menganggap proses pembelajaran IPS membosankan, monoton, tidak menyenangkan, daya ingat berlebih, beragam dan keluhan lainnya, maka tidak dapat disalahkan. Namun keberadaan teknologi informasi akan memberikan energi yang positif untuk penelitian dan pembelajaran sosial. ${ }^{18}$

Masih minimnya pemanfaatan pembelajaran IPS dengan menggunakan berbagai media pembelajaran. Di era pandemi Covid-19, guru dituntut untuk berkreasi dengan media yang digunakan, berbasis teknologi untuk membantu siswa mencapai tujuan pembelajaran dan menghadapi era milenial dengan memerlukan inovasi agar berkembang. Development juga bisa memodifikasi konten yang ada, kemudian mengemasnya sesuai waktu dan kebutuhan tertentu. Agar siswa mudah memahami maka inovasi guru juga tak bisa dipungkiri. ${ }^{19}$

\section{Inovasi Pembelajaran IPS Google Classroom}

Studi mata pelajaran ini berdasarkan pada hubungan kemasyarakatan, kondisi geografis di dunia, Indonesia, hubungan ekonomi dengan masyarakat, bahkan keterkaitan pada budaya yang beradaptasi dengan situasi, kondisi, dan penerapan ilmu tertentu baik melalui metode pendidikan atau psikologis, serta kelayakan dan signifikansinya bagi siswa dan kehidupan mereka. Menurut Nursid, materi IPS bertujuan untuk menumbuhkan potensi siswa agar tanggap terhadap problematika sosial yang terjadi di masyarakat, memiliki sikap positif dalam mengoreksi segala ketidakseimbangan yang terjadi, serta pandai mengatasi setiap masalah sehari-hari yang mengganggu kehidupan pribadi dan hubungan sosial. $^{20}$

Sejak dicetuskan masa darurat pandemi, peluang memanfaatkan kompetensi guru dikaitkan dengan teknologi digaungkan. Guru inovasi merupakan guru yang mampu memberikan warna baru demi kemasalahatan tujuan pendidikan melalui proses belajar dan mengajar. Tidak bisa jalan apabila dukungan teknologi tidak menyertainya.

Pengembangan teknologi memberikan peluang bagi pembelajaran untuk bisa menerarapkan pembelajaran daring dengan e-learning. Proses belajar dari tatap muka menjadi daring. Beberapa keuntungan untuk e-learning pendidikan adalah sebagai beikut:

a. Sumber informasi beragam dan terlampaui besar

18 Nur Lailatus Zahroh. 2015. E-learning Sebagai Inovasi Dalam Pemeblajaran IPS Tantangan Dan Peluang. Seminar Nasional Teknologi Pendidikan UM. Hal. 502-503.

19 Durotun Nafisah, Abd. Gofur. 2020. Pengembangan Media Pembelajaran Scan Barcode Berbasis Android Dalam Pembelajaran IPS. EduTeach: Jurnal Edukasi dan Teknologi Pembelajaran, 1 (2) Hal. 145-146.

20 Yulia Suriyanti, Munawar. 2019. Thoharudin Pemanfaatan Media Pembelajaran IPS Untuk Meningkatkan Keterampilan Guru IPS Terpadu. JPPM LPIP UMP. 3(1), Hal. 118. 
b. Peningkatan aksesibilitas belajar

c. Peningkatan kualitas pembelajaran

d. Informasi baru dan program baru dapat diadopsi dengan cepat

e. Proses belajar lebih fleksibel, tidak terikat ruang dan waktu. ${ }^{21}$

Penerapan e-learning dapat dilihat dengan adanya kemudahan aplikasi yang disbeut dengan google classroom. Google classroom dinilai efektif untuk pembelajaran kumpulan ilmu sosial karena tampilan google classroom yang mudah dipahami, digunakan, dipelajari dan diakses. Menurut penelitian Iftakhar (2016), keunggulan googlecClassroom antara lain:

a. Mudah digunakan: Desain google kelas sengaja menyederhanakan antarmuka pengajaran dan opsi untuk mengirim dan melacak tugas; itu juga menyederhanakan komunikasi dengan seluruh mata pelajaran atau individu melalui pemberitahuan streaming dan email.

b. Hemat waktu: Google Kelas bertujuan untuk mempercepat waktu. Ini mengintegrasikan dan mengotomatiskan penggunaan aplikasi Google lainnya, termasuk dokumen, slide, dan spreadsheet, serta proses distribusi dokumen, penilaian, dan umpan balik antara guru dan siswa. Penilaian formatif, serta menyederhanakan dan menyederhanakan umpan balik.

c. Fleksibel: Aplikasi ini mudah diakses dan dapat digunakan oleh guru dan siswa dalam pembelajaran tatap muka dan dalam lingkungan online sepenuhnya. Hal ini memungkinkan pendidik untuk mengeksplorasi dan memengaruhi metode pembelajaran yang lebih mudah dibalik, dan untuk mengotomatiskan serta mengatur tugas, pengumpulan, dan komunikasi.

d. Gratis: Selama mereka memiliki akun Gmail gratis, siapa pun dapat menggunakan Google Kelas itu sendiri untuk menyiapkan kursus di Google Kelas, hanya dengan mendaftarkan akun Google.

e. Ramah seluler: dapat dikenakan pada smarthphone lewat aplikasi atau web. ${ }^{22}$

Meskipun begitu, terdapat kesulitan sejak awal menggunakan google classroom siswa kurang memahami materi yang dibagikan oleh guru, terutama materi berupa berhitung. Selain itu, internet terkadang tidak begitu bersahabat, sehingga siswa bukanlah pilihan terbaik saat materi pembelajaran dibagikan oleh guru di kelas, terutama materi video. ${ }^{23}$ Meskipun Aplikasi ini akan membantu guru dalam menerapkan pembelajaran onlinenya. Aplikasi ini sangat mudah dioperasikan dan murah. Aplikasi ini menjadi solusi bagi guru

${ }^{21}$ Daryanto, Inovasi Pembelajaran Efektif, (Bndung: Yrama Widya, 2013), hal 50.

22 Andira Permata, Yoga Budi Bhakti. (2020). Keefektifan Virtual Class dengan Google Classroom dalam Pembelajaran Fisika Dimasa Pandemi Covid-19. JIPFRI, 4(1), hal 32.

${ }^{23}$ Maya Mahitsa Agung Mahardini. (2020). Analisis Situasi Pengggunaan Google Classroom Pada Pembelajaran Daring Fisika. Jurnal Pendidikan Fisika, 8(2), hal 220. 
untuk menerapkan pembelajaran daring yang selama ini terkendala oleh biaya dan alat pendukung yang tidak murah. ${ }^{24}$ Realitanya masih sedikit guru yang menggunakan aplikasi ini, sehingga pada saat membaca artikel ini guru dapat memanfaatkan teknologi e-learning sebagai media pembelajaran daring di masa pandemi. Dengan kelebihan dan kekurangan google classroom sebagai bentuk inovasi pemanfaatan teknologi IPS mampu menghadirkan kesempatan baru bagi guru dan siswanya bereksplorasi sesuai dengan zamannya.

\section{PENUTUP}

Masa pandemi memberikan peluang pembelajaran berbasis teknologi di Indonesia. Memanfaatkan teknologi bagi dunia pendidikan memiliki keuntungan tersendiri untuk peningkatan kualitas pendidikan. Pemanfaatan teknologi berkaitan dengan E-Learning sebagai bentuk konsolidasi kebutuhan belajar lewat proses pembelajaran dengan media yang digunakan di E-Learning. Situasi itu sangat diperlukan di situasi pandemi. Gerak langkah dibatasi secara fisik, pembatasan kontak fisik antar sesama membuka peluang bagi dunia pendidikan. Pengembangan ini disesuaikan dengan perkembangan zamannya dengan tidak mengurangi esensi pendidikan yang membangun peradaban lewat pengembangan intelektual, emosional, dan spiritual. Perkembangan zaman elemen paling berkenaan adalah pendidik dan peserta didik. Pendidik dituntut membuat pembelajaran yang aktif, dan inovatif. Melalui google classroom pembelajaran tanpa kontak fisik secara langsung bisa dilakukan. Mudahnya pengaksesan dan tidak membutuhkan banyak kuota seharusnya dimaksimalkan dengan baik. Kontribusi google classroom memberikan warna baru terhadap proses pembelajaran daring. Meskipun begitu perlu adanya peninjauan lebih lanjut tentang dampak dan upaya meningkatkan komponen daring di masa selanjutnya.

24 Bayu Kurniawan1, Agus Purnomo2, Idris. (2020). Pelatihan Penggunaan Aplikasi Google Classroom Sebagai Upaya Peningkatan Pembelajaran Online. International Journal of Community Service Learning, 4(1), hal 2. 


\section{DAFTAR PUSTAKA}

Andira Permata, Yoga Budi Bhakti. (2020). Keefektifan Virtual Class dengan Google Classroom dalam Pembelajaran Fisika Dimasa Pandemi Covid-19. JIPFRI, 4(1), hal 32.

Bayu Kurniawan1, Agus Purnomo2, Idris. (2020). Pelatihan Penggunaan Aplikasi Google Classroom Sebagai Upaya Peningkatan Pembelajaran Online. International Journal of Community Service Learning, 4(1).

Daryanto. 2013. Inovasi Pembelajaran Efektif. Bandung: Yrama Widya.

Dede Rahmat Hidayat, Ana Rohaya, Fildzah Nadine, \& Hary Ramadhan. (2020). Kemandirian Belajar Peserta Didik Dalam Pembelajaran Daring Pada Masa Pandemi COVID -19. Perspektif Ilmu Pendidikan, 34(2).

Kukuh Andri Aka. (2017). Pemanfaatan Teknologi Informasi Dan Komunikasi (TIK) Sebagai Wujud Inovasi Sumber Belajar Di Sekolah Dasar. ELSE, 1(2a).

Marzuki. 2005. Metodologi Riset. Yogyakarta: Ekonisia.

Maya Mahitsa Agung Mahardini. (2020). Analisis Situasi Pengggunaan Google Classroom Pada Pembelajaran Daring Fisika. Jurnal Pendidikan Fisika, 8(2).

Muhadjir, Noeng. 2002. Metodologi Penelitian Kualitatif. Yogyakarta: Rake Sarasin.

Nafisah, Durotun Abd. Gofur. 2020. Pengembangan Media Pembelajaran Scan Barcode Berbasis Android Dalam Pembelajaran IPS. Edu Teach: Jurnal Edukasi dan Teknologi Pembelajaran, 1 (2)

Nazir, Moh. 1999. Metode Penelitian. Jakarta: Ghalia Indonesia.

Nur Lailatus Zahroh. 2015. E-learning Sebagai Inovasi Dalam Pemeblajaran IPS Tantangan Dan Peluang. Seminar Nasional Teknologi Pendidikan UM.

Rizki Setiawan, Eti Komalasari. (2020). Membangun Efektivitas Pembelajaran Sosiologi Di Tengah Pandemi COVID-19. Edusocius, 4(1).

Suriyanti, Yulia. Munawar. 2019. Thoharudin Pemanfaatan Media Pembelajaran IPS Untuk Meningkatkan Keterampilan Guru IPS Terpadu. JPPM LPIP UMP. 3(1).

Zed, Mestika. 2014. Metode Penelitian Kepustakaan. Jakarta: Yayasan Pustaka Obor Indonesia. 